\title{
The Effect of Increasing Electricity Price on the Price of Groundwater and Profitability of Agricultural Production
}

\author{
Morteza Tahami Pour Zarandi,"*, Tahere Rahmani \\ ${ }^{1}$ Assistant Professor, Department of Economics \& Political Science, Shahid Beheshti University, Tehran, Iran \\ ${ }^{2} \mathrm{MA}$ in Economics, Department of Economics \& Political Science, Shahid Beheshti University, Tehran, Iran \\ *Corresponding author: m_tahami@sbu.ac.ir
}

\begin{abstract}
The agricultural sector is the largest water user in Iran, therefore, the government plans to increase water cost in this sector by increasing the price of electricity used by agricultural wells, thereby helping to reduce water losses. This research aimed to study the effect of increasing water price on agriculture profit. For this purpose, the cost of agricultural water was calculated in Qazvin province of Iran, for different electricity tariffs of the agricultural, industrial, and public sector of year 2015 by using economic appraisal method, which indicated that the cost of agricultural water was $0.035,0.052$ and 0.094 US\$, respectively. Then, the volume of water consumptions and water price share in the cost of production and agriculture profitability were determined for five major crops in Qazvin province. The results indicated that a substantial change has taken place in the water price share, leading to negative profit in agriculture.
\end{abstract}

Keywords: irrigation cost, economic appraisal method, electricity tariff, groundwater, profitability

Cite This Article: Morteza Tahami Pour Zarandi, and Tahere Rahmani, "The Effect of Increasing Electricity Price on the Price of Groundwater and Profitability of Agricultural Production." American Journal of Water Resources, vol. 6, no. 1 (2018): 15-24. doi: 10.12691/ajwr-6-1-3.

\section{Introduction}

Agriculture is the main consumer of water in the world and $93 \%$ of the annual water is consumed by this sector. It is predicted that water demand in urban areas and industrial usage doubled from 1995 to 2025 in developed countries encountering water scarcity. Supplying the needed water for irrigation is also at risk and this section is economically considered as the inefficient and the largest consumer of water. Agriculture is the largest consumer of water in Iran. Due to water scarcity in many regions of the country and increasing the competitiveness of other sectors of the economy with agriculture over water, it seems that the incremental increase in the economic value of water in agriculture is essential. It is expected that the increasing the price of water leads to an increase in water efficiency and economic surplus water use in agriculture [1]. Increasing water price is regarded as one of the ways considered by policymakers to improve water use, although this policy has not been operated in the agriculture sector, considering demand and supply sides of the economy.

In recent years, the real value of water is regarded as the dominant issue at the international level in the field of water scarcity. The price is willing to pay by the consumer for using the available resources indicates its final value. It is difficult to estimate the final value of water, since there is no market for water - if there was a market for water, it cannot be formal. In addition, water consumers are not faced with the economic value of water, especially in the agricultural sector which allocated high proportion of each country's total water consumption, due to high subsidies paid for water in agriculture by government [2].

Some argue that water pricing policies significantly improve the status of water management, partially or completely covers water service fees, enables the rational use of the water through the impact on consumer behavior, and provides investment in sustainable resources through funding, especially in irrigated agriculture [3].

Water pricing is regarded as one of the tools used by government for water demand management. Currently, the water price in agriculture sector has a significant difference with economical optimized price in Iran. The high dependence of Iran agriculture on government subsidies and traditional technologies of irrigation system are regarded as two reasons, which make it impossible to measure the amount of water used for irrigation. However, in recent years and according to the fifth development plan, some actions were adopted by which the irrigation efficiency increased to $44 \%{ }^{1}$. Rising electricity price used in water wells in this sector is one method implemented by the government for increasing and controlling agriculture water price. For this purpose and according to the law of acceleration of electrifying agricultural wells, approved in 1999, the government plans to electrify the pumps of water wells. The reduction of environmental

\footnotetext{
${ }^{1}$ According statistics office of Ministry of Agriculture.
} 
pollution and fossil fuel consumption are considered as the benefits of using this regulation in the agricultural sector. Therefore, a lot of Iran agricultural wells are electrified, based on the law. Government allocate many funds to the electrification of agricultural water wells. Electricity tariff in 2015 for agriculture sector is 0.003 US\$ per $\mathrm{kWh}$, while it is 0.06 US\$ for public sector, as the highest electricity tariff. Comparing these numbers shows the high subsidies that the government has allocated to agriculture sector. The government intends to increase agricultural electricity tariffs in the second phase of subsidies reform, leading to an increase in agricultural water cost. The purpose is optimizing water use and increase efficiency in this sector.

The present study aims to estimate the price of water, using economic appraisal method (average cost) and evaluate the effect of increasing the price of water on agriculture sector profitability, and optimize water use and increase efficiency in this sector. Therefore, three electricity tariffs, including electricity tariff for agricultural, industrial and public sectors are used. First, the water price for the electrified wells was calculated by using electricity tariff for agricultural sector and compared with the results of water prices based on electricity tariffs for industrial and public sectors. Then, the current agriculture water cost and water price share in the cost of agricultural production was calculated by using the information of irrigation and production cost, taken from Ministry of agriculture and NETWAT software ${ }^{2}$. Finally, the effects of water pricing on agriculture were examined by using the calculated water prices and the new version of water price share in the cost of agricultural production was calculated and its impact on agricultural gross profit was estimated.

Qazvin Province, located in the central district of Iran, covers 15821 square kilometers. Qazvin Plain with an area of 500 thousand hectares covers 320000 hectares of irrigable lands, among which only 160 hectares are irrigated by groundwater and surface water. Based on these conditions, lack of water in this area is inevitable, especially when water is used in urban and rural areas, where the industry increases water demand.

Based on the data from Iran Water Resources Management Organization, 7163 wells were active in Qazvin province in 2009, among which 4567 (64\%) were dedicated to agricultural sector, which indicates high share of agricultural consumption in water resources in Qazvin province. The Figure 1 illustrates the distribution of wells in Qazvin province in 2009, with regard to different uses. It is worth noting that about $78 \%$ percent of these agricultural wells use electricity.

This paper is organized as follows: In section two, the studies done about agriculture water price are reviewed. In the third section, the research methodology is introduced. In section four, the price of water extracted from underground sources are estimated, using data taken from

\footnotetext{
${ }^{2}$ NETWAT software is applied for water requirement of garden plants and crops in Iran. This application included functional statistics and information, which is used in many studies about irrigation projects, dams, drainage, and projects related to water engineering. This software is the result of "net irrigation requirement for crops and garden plants in Iran" plan, which is done by the Ministry of agriculture and the Iran meteorological organization.
}

Iran Water Resources Management Organization and the method is introduced in section three. In the fifth section, agricultural gross profit is calculated by using data from Ministry of Agriculture and the effect of water price on irrigation efficiency and agriculture profitability is examined. Finally, conclusions are made in sections six and references are mentioned in final section.

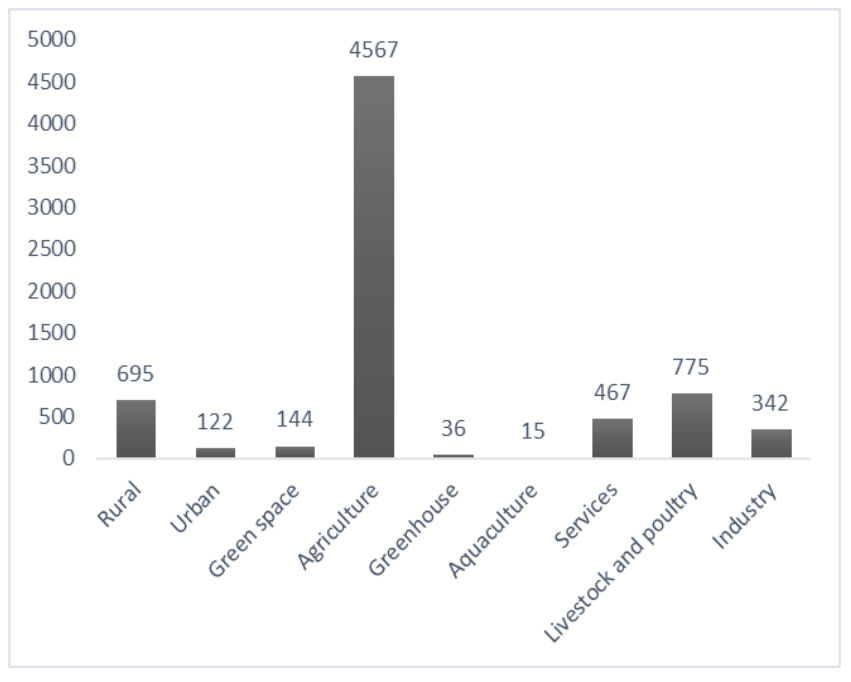

Figure 1. Distribution of Qazvin Province wells in 2009

\section{Previous Studies}

There is a considerable amount of literature about water pricing in agriculture sector:

Asadi et al. [4] calculated the price of agricultural water and average production cost of one hectare of different crops and estimated the water use rate based on Gardner method in 1996 in Qazvin Plain. Base on the results, the average price per cubic meter of irrigation water supply was higher than 36 Rials (0.001 US\$) in 1996 in Qazvin Plain, while the current price of irrigation water was about 5.6 Rials (0.0002 US\$) per cubic meter.

Tahamipour et al. [5] studied irrigation water price in Fars province based on engineering economic method and found that the weighted average price of one cubic meter of surface and ground water for agricultural purposes, in Fars Province, were 860 (0.03 US\$) and 544 (0.02 US\$) Rials, respectively, which indicated a significant difference, compared to the current water tariff (147 Rials (0.004 US\$)) for every cubic meter) for crops in the province. Therefore, they suggested that the agricultural water tariffs system must be based on real water price and the policy objectives, adopted in different periods of time

Soleimani et al. [6] calculated the price of water per cubic meter and water use efficiency, as two important factors in dry agriculture area and examined the added value of irrigation as an economic-ecological factor for major products of Darab area in Fars province. The results showed that an increase in water productivity is not the necessary conditions should be provided for making decisions, and the added value should be regarded as the main factor for making appropriate decisions to determine the type of farming system in the region.

Mortazavi et al. [7] studied irrigation water pricing in 2012 in Qazvin Plain as 1,400 Rials (0.043 US\$) for each 
cubic meter and concluded that the government subsidies were 1200 Rials (0.037 US\$) per cubic meter of water, based on the price of agricultural water in that year (197 Rials (0.006 US\$)).

In their study, Samal et al. [8] focused on the economic value of water for more efficient management, especially in the agricultural sector among developing countries by determining the price of water and management reform.

Renwick [9] estimated the price of water used in agriculture and fisheries in Sri Lanka by using Total Economic Valuation (TEV) and emphasized on the role of development and management of irrigation in economic and financial efficiency.

Hellegers et al. [10] determined the economic value of water used in irrigation in the Basin of Moses River in India, where the agriculture relies on government subsidies. Based on the results, the price of water is different according to product type, region and even in different seasons.

Thabet et al. [11] investigated the effect of water management policies on agriculture in Tunisia and Morocco and emphasized the role of low price of water on crop selection. In other words, farmers prefer to implant those crops having high profitability although they impose a higher pressure on water resources. In fact, the reduction of public subsidies on water leads to a reduction in the farmers' income, but can be compensated through savings in public spending and appropriate and optimal water resource use.

According to the law of acceleration in electrifying agricultural irrigation well motors, approved in 1999, the government of Iran plans to electrify irrigation well motors. Among the benefits of this plan, we can refer to a reduction in the farmers' need to fossil fuels, a saving in the whole country and a reduction in environmental pollution. Therefore, by considering the aids allocated for electrifying wells, high subsidies (95\%) is also paid to electricity in agricultural sector, which confirm the support of the agricultural sector and its development by the government.

On the other hand, an increase in electricity tariffs in agricultural sector is one of the programs adopted by Iran government in the second phase of subsidies reform, which affects the electricity consumption, the price of water for agricultural sector and the farmers' incomes. By considering all these problems, the present study aims to investigate the effect of rising electricity price on the agricultural sector. For this purpose, the cost of agricultural wells water in Qazvin province were calculated by considering current electricity tariffs for agricultural, industrial and public sectors and the effects of water pricing on agriculture gross profit were estimated.

\section{Methodology}

In the economic method, all investment, replacement and maintenance and utilization costs in the life time of project are calculated and the costs of water is calculated by drawing cash flow cost table. The economic appraisal method considered the time value of money as well.

In this paper, economic appraisal method and average cost approach were used for water pricing. It is worth noting that the calculation was done by using constant price and without considering inflation. In order to estimate the average cost of well water, the cost of extraction and distribution of water, including both fixed and variable costs were taken into consideration. Fixed costs included the investment costs done for water supply and distribution, which is regarded as the invest stock and gradually depreciates in the life time of the project. Variable costs included the cost of maintenance and utilization, as the current cost, which is annually consumed for continuous use and water utilization. However, these two pricing components are different. In the economic appraisal method, the value of investments made in different years, with an appropriate discount rate, is converted to the value of the year when the price of water it is calculated. Then, the total value of these investments, which converted to the present value as well as their annual depreciation cost are calculated. Annual depreciation cost is accumulated by the cost of maintenance and utilization in base year to annual total cost of supply and distribution of water is obtained. The total cost is divided by the annual volume of extraction and distribution water, resulting the average price per cubic meter of water.

$$
P=\frac{\sum A C+O \& M}{W}
$$

P: Average cost of well water in 2015

AC: Annual investment in 2015.

The annual investment is calculated by using Capital Recovery Factor (CRF) and multiplying it by the value of updated investments.

$$
C R F=\frac{i(1+i)^{n}}{(1+i)^{n}-1}
$$

In this formula (n) is useful life and (i) represents a social discount rate or the interest rate $(8 \%$ in the present study).

$\mathrm{O} \& \mathrm{M}$ : The variable related to current costs in agricultural irrigation wells include the costs of annual repairing and maintenance and the cost of well power consumption. Under Circular No. 270/47819 approved in 1997 by Ministry of Energy, these costs are considered as a percentage of the initial investment costs. The share of maintenance and utilization costs of the total initial investment for the facility of ground water, upon this Circular, is $5.2 \%$. In the present study, the same procedure was used to calculate the current cost.

$\mathrm{W}$ : represents the volume of extracted water, obtained by multiplying the well Debi in total work hours per year in 6.3 value.

In this study, the average cost per cubic meter of the extracted water from electric wells in Qazvin province was estimated to calculate the cost of electric well irrigation water. For this purpose, all the information about water wells in Qazvin province was obtained from the Water Resource Management Organization and the data was from the last census report in 2009. The related information for the components of the water price of irrigation wells was collected from the relevant experts and the basis price list of wells in 2015, determined by Deputy for Strategic Planning and Control and the 
electricity tariffs in 2015, were extracted from the Ministry of Energy in order to calculate the price of water of irrigation well [12-17].

\section{Results}

\subsection{Model estimation and data analysis}

The average cost of agriculture water per cubic meter was calculated and determined. As shown in Figure 1, the main well water of Qazvin province is used by agricultural sector and the dominant well pumps use electricity. In the present study, the price of water was calculated for electric agricultural wells.

Based on well's depth, agriculture irrigation wells are classified into three groups: $0-100 \mathrm{~m}$ as shallow wells, $100-200 \mathrm{~m}$ as deep wells and $200-300 \mathrm{~m}$ as very deep wells. These categories are based on the basis price list of wells for 2015 extracted from Deputy for Strategic Planning and Control. Table 1 indicates the parameters and technical characteristics of wells in each category, which were calculated by averaging.

As shown in Table 1, an increase in the depth of the well leads to an increase in the withdrawal of groundwater, a reduction in the level of underground water resources, and the pressure on groundwater resources. The annual extraction rate for deep and very deep well group are close to each other, due to a small number of wells with more than two-hundred-meter depth. Regarding more than 3000 wells, only 26 wells had depth more than two hundred meters and the rest were related to other two groups. It is worth mentioning that the annual average depletion of water in the less than 100-meter depth wells is very low, which are significantly different from the average depletion of other groups.

In order to calculate the price of irrigation water, the average price of water in each group was calculated by using the existing data and the average price for one cubic meter of water from agricultural wells in Qazvin province was calculated by using a weighted average based on the average annual depletion of water in each group as weight.

The fixed costs are related to investment and extraction costs, such as the well drilling, and installation and equipment costs. Well drilling costs are related to the equipment and plant removal, drilling wells, providing and installing pipe, testing and field operations, and workers' wage, which were obtained from "the basis price list of wells in 2015", extracted from Deputy for Strategic Planning and Control. Each of these items has different components, by which the costs calculated based on the technical specifications of wells such as depth, type and thickness of wells' pipe and the drilling place for the sample well. It should be noted that, these costs might be adjusted by a factor in each province in Iran, as it was 1.05 in Qazvin province. Table 2 shows the results of the well drilling cost for shallow, deep and very deep well group and based on its components.

As it is evident from Table 2, the total drilling cost about 56, 90, and 125 thousand US\$ among shallow wells, deep wells, very deep wells, respectively.

The cost of well construction and equipment include the cost spent for the pump and electric motor, electrical panel, cable, Wellhead, installation, electricity branch, and other miscellaneous costs. These items also depend on the technical specifications of the well. The cost of sample well facilities are calculated based on these specifications and their market prices. Table 3 indicates the results of calculation.

Table 1. Parameters and technical characteristics of irrigation wells in Qazvin province

\begin{tabular}{|l|c|c|c|}
\hline & Shallow wells & Deep wells & Very deep wells \\
\hline The numbers of wells & 1486 & 1344 & 26 \\
\hline The average depth of wells(m) & 224 & 129 & 33 \\
\hline The average annual depletion(m3) & 110752 & 601087 & 735594 \\
\hline The average engine power (KW) & 55 & 125 & 158 \\
\hline Average days of work per year & 219 & 250 & 241 \\
\hline Average working hours per day & 8 & 20 & 21 \\
\hline
\end{tabular}

Source: Water Resources Management organization.

Table 2. The estimated drilling cost in shallow, deep, and very deep group (US\$)

\begin{tabular}{|l|c|c|}
\hline & Shallow wells & Deep wells \\
\hline Equipping and removing the workshop & 5907.36 & 6228.50 \\
\hline Manually Drilling Method & 6064.55 & 0 \\
\hline Striking Drilling Method & 13001.59 & 35134.71 \\
\hline Rotational Drilling Method & 6386.87 & 12100.58 \\
\hline The cost of supplying and installing pipes & 13527.23 & 22511.87 \\
\hline Tests and field operations & 10003.24 & 13144.72 \\
\hline Wage tasks & 1188.54 & 16127.81 \\
\hline Total Drilling Costs & 56079.39 & 17053.17 \\
\hline
\end{tabular}

Source: researcher calculations. 
Table 3. Estimated cost of supplying the construction and equipment of wells (US\$)

\begin{tabular}{|l|c|c|}
\hline & Shallow wells & Deep wells \\
\hline Cost of the cable & 504.43 & 1971.88 \\
\hline Cost of electricity branch & 2960.51 & 6728.42 \\
\hline Cost of water pump & 1850.60 & 1850.60 \\
\hline Power transformer & 3701.19 & 3701.19 \\
\hline Electrical Panel & 246.75 & 246.75 \\
\hline Install round control & 1758.06 & 1758.06 \\
\hline Wellhead equipment & 832.77 & 832.77 \\
\hline Total cost of facilities & 11854.31 & 1758.06 \\
\hline
\end{tabular}

Source: researcher calculations.

As shown in Table 3, the total cost of supplying the construction and equipment in shallow, deep, and very deep wells is about 11,17 , and 20 thousand US\$, respectively.

The current cost of agriculture wells water is related to annual maintenance and electricity consumption. Utilization and maintenance costs begin with well operation and are considered in the annual calculation till the end of operation.

The electricity cost was calculated by multiplying the average engine power and electricity tariff per kilowatt hour and the annual pump operation. As mentioned before, the present study aimed to investigate the effect of rising electricity prices on agriculture. Therefore, the electricity tariff for the agricultural, industrial, and public sector was implemented in three different conditions. Finally, the calculation was done for each condition separately.

According to the announced tariffs by the Ministry of Energy for 2015, electricity tariffs for production purposes (water and agriculture) is 0.003 US\$ per $\mathrm{kWh}, 0.02$ US\$ per kWh for industrial use and 0.06 US\$ per kWh for public consumption. The price difference amongst the tariffs indicates a high volume of agricultural sector subsidies, provided by the government. In order to determine the impact of electricity tariff increasing on the price of agricultural water, the current cost was separately calculated for the different electricity tariffs for three sectors, as shown in Table 4, Table 5, \& Table 6.
The results (See Table 4) indicated that total current cost is about 2025 US\$ for shallow wells, about 4816 US\$ for deep wells and 6360 US\$ for very deep wells, based on the electricity tariff for agriculture sector $(0.003$ US\$).

As observed in Table 5, total current cost is about 3, 15, and 19 thousand US\$ for shallow, deep, and very deep wells, respectively, regarding the electricity tariff for industrial sector (0.02 US\$).

As it is clear from Table 6, the total current cost, based on the electricity tariff for public sector (0.06 US\$), is about 7, 39, and 51 thousand US\$ for shallow well, deep well, and very deep wells, respectively.

Now, based on the volume of annual depletion of irrigation well (See Table 1), the estimated fixed and current costs (see Table 2 to Table 6), and using economic appraisal method, the price of water per cubic meter was calculated by forming the cash flow table and the application of the average price method, mentioned in the previous section. $8 \%$ discount rate and 35 -year evaluation period were used to calculate the annual uniform fee. The useful producing life of the well and wellhead facilities were considered 20 and 10 years, respectively, based on field information and the expert opinions. Table 7 indicates the agricultural wells water price for three different electricity tariffs and well depth. Based on the weight of average annual water depletion in each category, the weighted average cost was calculated for the province.

Table 4. Estimated current cost based on electricity tariff for agricultural sector (US\$)

\begin{tabular}{|l|c|c|c|}
\hline & Shallow wells & Deep wells & Very deep wells \\
\hline Annual maintenance costs & 1698.34 & 2695.55 & 3647.10 \\
\hline Power cost & 326.93 & 2120.47 & 2712.98 \\
\hline Total current costs & 2025.27 & 4816.03 & 6360.08 \\
\hline
\end{tabular}

Source: researcher calculations.

Table 5. Estimated current cost, based on electricity tariff for industrial sector (US\$)

\begin{tabular}{|l|c|c|c|}
\hline & Shallow wells & Deep wells & Very deep wells \\
\hline Annual maintenance costs & 1698.34 & 2695.55 & 3647.10 \\
\hline Power cost & 1946.70 & 12626.46 & 16154.55 \\
\hline Total current costs & 3645.04 & 15322.01 & 19801.65 \\
\hline
\end{tabular}

Source: researcher calculations. 
Table 6. Estimated current cost, based on electricity tariff for public sector (US\$)

\begin{tabular}{|l|c|c|c|}
\hline & Shallow wells & Deep wells & Very deep wells \\
\hline Annual maintenance costs & 1698.34 & 2695.55 & 3647.10 \\
\hline Power cost & 5747.96 & 37281.78 & 47699.09 \\
\hline Total current costs & 7446.30 & 39977.34 & 51346.19 \\
\hline
\end{tabular}

Source: researcher calculations.

Table 7. Agricultural wells water price for Qazvin Province

\begin{tabular}{|l|c|c|c|c|}
\hline Water cost (US\$ per cubic meter) & Shallow wells & Deep wells & Very deep wells & Province average \\
\hline Agricultural electricity tariff & 0.090 & 0.030 & 0.031 & 0.035 \\
\hline Industrial electricity tariff & 0.104 & 0.046 & 0.050 & 0.052 \\
\hline Public electricity tariff & 0.139 & 0.087 & 0.092 & 0.094 \\
\hline
\end{tabular}

Source: researcher calculations.

The maximum cost of water belonged to shallow wells, while an increase in well depth led to an increase in the cost of extraction and distribution of water and the volume of extracted water and finally the price of water, in deep and very deep categories. However, the volume of extracted water in shallow wells is very low, compared to the cost of extraction, which is regarded as the main reason for the high cost of water in this category.

In the Figure 2, the diagram of the average of the water price, considering the different electricity tariffs are shown.

\section{- Province Average}

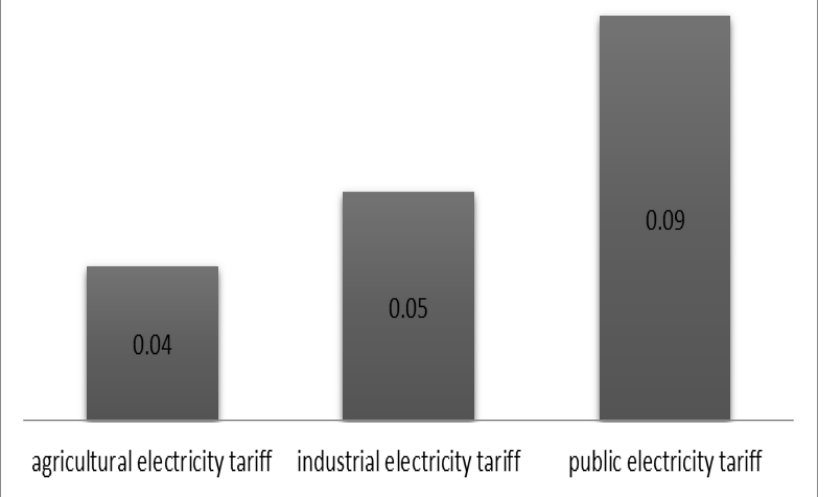

Figure 2. Water price in Qazvin province for different electricity tariffs

As shown in Figure 2, an increase in electricity prices led to an increase in the price of agricultural water. The price of water was 0.035 US\$ when the price of electricity tariff for agriculture sector (0.003 US\$ (110 Rials)) was used for calculation while it was 0.052 US\$ when the price of industrial electricity tariff (0.02 US\$ (655 Rials)) was used, which means that the water price is getting almost 1.5 times higher. However, the water price was 0.094 US\$ when the public electricity tariff (0.06 US\$ (1934 Rials)) was used for calculation. Which is more than 2.5 times higher than the price of water for agricultural power tariff price (0.03 US\$).

\subsection{Estimating the Agriculture Gross Profit}

As mentioned in the previous section, an increase in electricity prices increases the price of water. Further, as water is the important input in agriculture, an increase in water price means an increase in production cost and a decrease in agricultural income and farmers' profit, having a negative impact on agricultural production. This section examines the effects of increasing water price on the farmers' gross profit.

For this purpose, the share of water price in agricultural production costs was estimated. Therefore, the data for production cost and agricultural information for the 20112012 were taken from Ministry of Agriculture website. In these years, about 12.38 million hectares were under cultivation, among which $53 \%$ and $47 \%$ were irrigated and rain-fed lands, respectively. In Qazvin province, this amount was $61 \%$ for irrigated and $38 \%$ for rain-fed lands, and more than $97 \%$ of agricultural production were from the irrigated lands. Based on the crop information taken from Ministry of Agriculture, among agricultural products, five products, which having the largest area under cultivation, were selected to examine the impact of water price on farmer's gross profit. The selected crops included wheat, barley, corn, alfalfa and tomatoes. Based on information taken from Ministry of Agriculture, Table 8 indicates the detailed information about the area under cultivation and production for irrigated land, the total cost of production, gross profit and the cost of production per every kilo related to these crops.

Table 8. Cultivation information related to five major crops in Qazvin province during 2011-12

\begin{tabular}{|c|c|c|c|c|c|}
\hline Product type & $\begin{array}{c}\text { Area under } \\
\text { cultivation (hectares) }\end{array}$ & Production (tone) & $\begin{array}{c}\text { Gross value of } \\
\text { production (US\$) }\end{array}$ & $\begin{array}{c}\text { Total production } \\
\text { cost (US\$) }\end{array}$ & $\begin{array}{c}\text { Gross profit } \\
\text { (US\$) }\end{array}$ \\
\hline Wheat & 281022 & 232764.07 & 911.11 & 485.36 & 426.31 \\
\hline Barley & 43129.8 & 117305.22 & 685.12 & 466.18 & 219.35 \\
\hline Corn & 20710.1 & 119816906 & 1391.48 & 848.93 & 542.54 \\
\hline Alfalfa & 17852.2 & 225075.42 & 1414.41 & 886.78 & 527.63 \\
\hline tomato & 7251 & 309211.88 & 2837.89 & 1536.38 & 1301.51 \\
\hline
\end{tabular}

Source: Ministry of Agriculture. 
The production cost for the agricultural sector includes the cost related to preparation, implanting, planting and harvesting. Those costs related to water were done in the preparation and planting stages. In the data related to five major crops in Qazvin province, price of water belongs to planting stage. By dividing the price of water to total production cost, the share of water price is obtained from the total price of agricultural production. The results of the calculations for the five major crops are shown in Table 9. Netwat software is used to extract the net irrigation water requirement (cubic meters per hectare), calculated for different provinces and different agricultural products. Therefore, net irrigation water requirement was extracted for five top products in Qazvin Province. The gross irrigation water requirement was achieved by applying efficiency rate. The efficiency rate was considered $40 \%$ for the first calculation. The current cost of water is estimated by dividing the irrigation water cost in planting stage on the gross irrigation water requirement. Table 9 indicates the related results for major agricultural products. As shown in Table 9, the average water price share of the production cost is $12 \%$ and the average price per cubic meter of water is about 0.007 US\$ based on the current conditions. However, regarding electricity tariff for agriculture sector, the estimated price of water is 0.035 US\$. Thus, these amounts indicate the high volume of subsidies paid to agriculture sector by the government. Using the gross value of agricultural production and decrementing the cost of production, the gross profit for each of the products can be calculated. The weighted average gross profit of five major agricultural products is 432.99 US\$, based on the weight of the area under cultivation for the crops. In fact, gross profit is 432 US\$.

\subsection{Gross Agricultural Profit by Using Estimated Water Prices}

As it was already mentioned, the actual price per cubic meter of agricultural water, was 0.007 US\$, based on the production cost while the price of water it was estimated to be 0.035 US\$, based on the electricity tariff for agricultural sector. The real price of water paid by farmers is even lower. In other words, the real price of water cannot cover the current costs. Now, what happens if the estimated water price is used for calculating the share of water prices in total cost of production and the farmer's gross profit? In order to answer the question, the weighted average cost per cubic meter of water, estimated regarding the agriculture electricity tariff ( 0.035 US\$) is multiplied by the gross irrigation water requirements of each of the major products and finally the cost of required water is estimated. For a more accurate estimation of the price of water share in production costs, the effect of new cost of required water is considered in the cost of production. Therefore, the results of new calculations are shown in Table 10.

As observed in the Table 10, the average of water price share in production cost is $39 \%$. In fact, the water price share is tripled in the cost of production if the water price is increased five times. Gross profit of each product is calculated by using the new gross value of production and total production costs. The weighted average gross profit of five major agricultural crops was 178.71 US\$, based on the weight of area under the cultivation for the crops. In other words, a reduction took place in the gross profit. Therefore, regarding 0.035 US\$ for the price of water per cubic meter, the profitability for agriculture sector decreased in Qazvin province and the profit has fallen about 254 US\$ based on Table 9.

Based on agricultural electricity tariffs, the gross profit decreased after calculating the estimated cost of water. It also decreased even more, when the estimated cost of waters were considered for calculation, regarding the industrial and public electricity tariffs, as the highest electricity tariffs. The results are indicated in Table 11 and Table 12.

As shown in Table 11, the average of water price share in production cost is 48 percent. In fact, when the price of water is increase seven times, there is a four-time increase in water price share in the cost of production. Using the new gross value of production and total production costs, gross profit of each product is calculated. The weighted average gross profit of five major agricultural crops (based on weight of area under the cultivation of crops) equals to 18.41 US\$. Based on the results in Table 9, the gross profit considerably decreased about 414 US\$. This is shown a significant reduction in agricultural profit.

Table 9. Water price share in the agricultural production cost in Qazvin (2011-2012)

\begin{tabular}{|c|c|c|c|c|c|c|}
\hline $\begin{array}{c}\text { Product } \\
\text { type }\end{array}$ & $\begin{array}{c}\text { Water } \\
\text { cost }\end{array}$ & $\begin{array}{c}\text { gross value of } \\
\text { production }\end{array}$ & $\begin{array}{c}\text { Total production } \\
\text { cost }\end{array}$ & $\begin{array}{c}\text { Gross } \\
\text { profit }\end{array}$ & $\begin{array}{c}\text { Water cost share in } \\
\text { production cost(\%) }\end{array}$ & $\begin{array}{c}\text { Price of water - per cubic } \\
\text { meter(US\$) }\end{array}$ \\
\hline Wheat & 55.92 & 911.67 & 485.36 & 426.31 & 11.5 \\
\hline Barley & 54.50 & 685.54 & 466.18 & 219.35 & 11.7 & 0.0078 \\
\hline Corn & 105.78 & 1391.48 & 848.93 & 542.54 & 125 & 13 \\
\hline Alfalfa & 84.56 & 1414.41 & 886.78 & 527.63 & 0.0092 \\
\hline tomato & 166.55 & 2837.89 & 1536.38 & 1301.51 & 0.0061 \\
\hline
\end{tabular}

Source: Ministry of Agriculture and researcher calculations.

Table 10. Water price share in the production price based on agricultural electricity tariff

\begin{tabular}{|c|c|c|c|c|c|c|}
\hline Product type & Water cost & $\begin{array}{c}\text { gross value of } \\
\text { production }\end{array}$ & $\begin{array}{c}\text { Total } \\
\text { production cost }\end{array}$ & Gross profit & $\begin{array}{c}\text { Water cost share in } \\
\text { production cost(\%) }\end{array}$ & $\begin{array}{c}\text { Price of water - per } \\
\text { cubic meter(US\$) }\end{array}$ \\
\hline Wheat & 251.33 & 911.67 & 680.77 & 230.90 & 36.9 \\
\hline Barley & 205.79 & 685.54 & 617.48 & 68.06 & 0.035 \\
\hline Corn & 598.99 & 1391.48 & 1342.14 & 49.34 & 33.3 & 44.6 \\
\hline Alfalfa & 732.09 & 1414.41 & 1503.48 & -89.06 & 0.035 \\
\hline tomato & 966.09 & 2837.89 & 2027.49 & 810.39 & 0.035 & 48.7 \\
\hline
\end{tabular}

Source: Ministry of Agriculture and researcher calculations. 
Table 11. Water price share in the production cost, based on industrial electricity tariff

\begin{tabular}{|c|c|c|c|c|c|c|}
\hline Product type & Water cost & $\begin{array}{c}\text { gross value of } \\
\text { production }\end{array}$ & $\begin{array}{c}\text { Total } \\
\text { production cost }\end{array}$ & Gross profit & $\begin{array}{c}\text { Water cost share in } \\
\text { production cost(\%) }\end{array}$ & $\begin{array}{c}\text { Price of water - per } \\
\text { cubic meter(US\$) }\end{array}$ \\
\hline Wheat & 376.25 & 911.67 & 805.69 & 105.98 & 46.7 & 0.052 \\
\hline Barley & 308.08 & 685.54 & 719.76 & -34.23 & 42.8 & 0.052 \\
\hline Corn & 896.72 & 1391.48 & 1639.87 & -248.39 & 54.7 & 0.052 \\
\hline Alfalfa & 1095.9 & 1414.41 & 1867.36 & -452.95 & 58.7 & 0.052 \\
\hline tomato & 984.55 & 2837.89 & 2354.38 & 483.51 & 41.8 & 0.052 \\
\hline
\end{tabular}

Source: Ministry of Agriculture and researcher calculations.

Table 12. Water price share in the production cost based on public electricity tariff

\begin{tabular}{|c|c|c|c|c|c|c|}
\hline Product type & Water cost & $\begin{array}{c}\text { gross value of } \\
\text { production }\end{array}$ & $\begin{array}{c}\text { Total } \\
\text { production cost }\end{array}$ & Gross profit & $\begin{array}{c}\text { Water cost share in } \\
\text { production cost(\%) }\end{array}$ & $\begin{array}{c}\text { Price of water - per } \\
\text { cubic meter(US\$) }\end{array}$ \\
\hline Wheat & 673.64 & 911.67 & 1103.07 & -191.41 & 61.1 & 0.094 \\
\hline Barley & 551.58 & 685.54 & 963.27 & -277.73 & 57.3 & 0.094 \\
\hline Corn & 1605.46 & 1391.48 & 2348.61 & -957.14 & 68.4 & 0.094 \\
\hline Alfalfa & 1962.23 & 1414.41 & 2733.61 & -1319.19 & 71.8 & 0.094 \\
\hline tomato & 1762.72 & 2837.89 & 3132.55 & -294.66 & 56.3 & 0.094 \\
\hline
\end{tabular}

Source: Ministry of Agriculture and the researchers' calculations.

As indicated in the Table 12, the average of water price share in production cost is $62 \%$. In fact, when the price of water has increased to twelve times more than the present price, there an increase of five times in water price share in the cost of production. Gross profit of each product is calculated by using the new gross value of production and total production costs. The weighted average gross profit of five major agricultural crops (based on weight of area under the cultivation of crops) is -363.19 US\$. By considering 0.094 US\$ as the price of water per cubic meter, a loss of 363 US\$ takes place in Qazvin province agriculture.

As shown in the above tables, a decrease happened in the farmer's profit when water pricing was implemented regarding the current electricity tariff in agriculture sector as the lowest electricity tariff in Iran. Regarding the higher electricity tariff (industrial electricity tariff) in water pricing, the production cost considerably increased even more and reduction happened in profitability will be more. The weighted average of gross profit became negative indicating the net loss for the farmer when the public electricity tariff was regarded for estimating the price of water. The results indicated the sensitivity of water pricing policies in agriculture, regarding the necessity for an appropriate support on behalf of farmers and resources.

\subsection{Irrigation Efficiency}

As it was already mentioned, the irrigation efficiency was considered as $40 \%$ based on Table 9 - Table 12 . The reformation of irrigation system and development of new irrigation methods are regarded as the outcomes of increasing the price of water in agriculture sector, leading to an increase in the irrigation efficiency. In other words, an increase in irrigation efficiency will offset the price of water and decrease the farmers' losses. In order to investigate this issue, three scenarios were designed to see what happens to agricultural gross profit when an increase takes place in the price of water and irrigation efficiency. In first scenario, the change in irrigation efficiency duo to increase in the price of water was studied. As illustrated in Figure 3, increasing the price of water led to an increase in the irrigation efficiency.

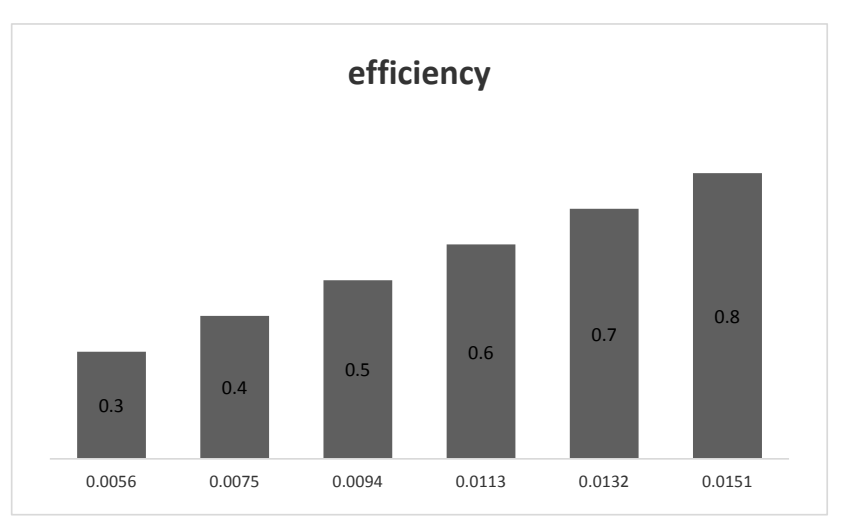

Figure 3. Effect of water pricing on irrigation efficiency

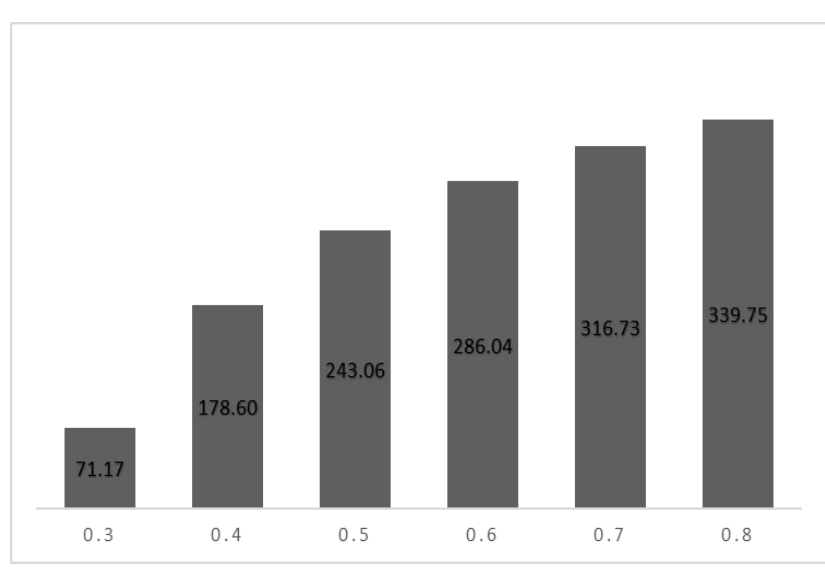

Figure 4. Effect of increasing irrigation efficiency on weighted average of gross profit

It is expected that an increase in irrigation efficiency leads to decrease the reduction in gross profit. In the second scenario, an increase in the irrigation efficiency from $30 \%$ to $80 \%$ was taken into consideration. For this purpose, the weighted average of gross profit was calcualted in each step. Therefore, based on the related data in Table 10, the electricity tariff of egriculture sector was used to calculate the price of water and weighted average gross profit. Based on the information obtained from the Ministry of agriculture and NETWAT software, 
the current weighted average gross profit is about 432 US\$. As illustared in Figure 4, an increase in irrigation efficiency resulted in decreasing the reduction in the gross profit, compared with the current weighted average of gross profit (about 432 US\$).

Finally, it is worth noting that the profit in agriculture should not be ignored in water pricing. In fact, there is a limit for increasing the price of water. As for third scenario, the information from the Ministry of Agriculture and NETWAT software were used to see the effect of increasing the price of water on the weighted average gross profit. Then, the price of water that makes the weighted average gross profit into zero was calculated. Results are shown in Figure 5.

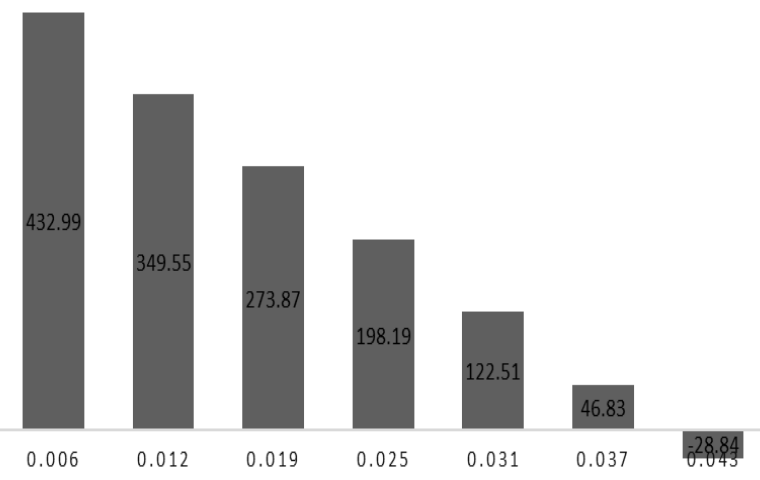

Figure 5. Effect of increasing the price of water on the profit of agriculture in Qazvin province

Based on the Figure 5, the weighted average gross profit is zero if the price of water increases to $0.041 \mathrm{US} \$$, representing the maximum possible increase which could be considered in water pricing and this price makes the farmers' gross profit zero. Therefore, no more increase should take place in the price of water because the profit becomes negative in higher prices and the agricultural activity is not logical.

\section{Conclusion}

In Iran, Government has allocated high financial support to the agricultural sector. About $95 \%$ of the electricity cost in the agricultural sector is paid by the government. According to the plans announced by the government for the implementation of the second phase of reforming the subsidies, an increase happens in electricity prices in the agricultural sector. Due to the dry climate of Iran and drought in recent decade, the major water needed for agriculture irrigation is supplied from underground resources. Therefore, an increase in electricity tariffs in agriculture sector means an increase in the cost of irrigation water. The present study evaluates the impact of increasing electricity tariffs on the framers' benefit. The cost of agricultural water was calculated by using current electricity tariffs for agricultural, industrial and public sector and the share of the water price was estimated in agricultural production cost and the agricultural gross profit by applying these costs.

The results of the study indicated that weighted average cost of agricultural water was 0.035 US\$ with regard to the agricultural electricity tariff while it was 0.052 US\$ for the industrial electricity tariffs. In other words, an increase of six times in the electricity tariffs leads to an increase of 1.5 times in the price of water. By considering the public electricity tariff, the price of water equals to 0.094 US\$ and an increase of 12 times in the electricity tariffs leads to an increase of more than 2.5 times in the price of water.

The average water price share in production cost is $12 \%$. It is worth mentioning that the average of current water price per cubic meter is 0.007 US\$, based on the information of production and planting cost extracted from Ministry of Agriculture, which is substantially lower than 0.035 US\$ as the obtained water price based on agricultural electricity tariff. The low real price of water and its small share in the production cost led to indiscriminate harvesting of underground water resources and low irrigation efficiency. Regarding the week and vulnerable nature of this sector as well as the dry and harsh climate of Iran, the allocation of high volume of subsidies and funds to agriculture sector by the government is considered as a policy to increase the farmer's welfare and improve agriculture sector. However, the continuation of this policies seems illogical, based on water and natural resource conditions and the continuation of current costly and wasteful agricultural system.

The profit becomes negative, using the estimated costs of agricultural water, based on different electricity tariffs to calculate gross profit. For example, when the weighted average costs of water are considered based on the public electricity tariff as the highest electricity tariffs, there is an increase from $12 \%$ to $63 \%$ in the share of water prices in the cost of production and a weighted average gross profit reaches -732 US\$ while the weighted average current gross profit is more than 162 US\$. Therefore, rising electricity prices and increasing the price of water lead to high losses in the agricultural sector.

An increase in electricity tariff and the price of water resulted in increasing cost and loss in agriculture sector, which is necessary; due to the drought in recent decades and severe damage that indiscriminate harvesting has created for underground water resources. Low efficiency in agriculture sector is related to the real low cost of water and agricultural production. It is expected that an increase in the price of water motivate farmers to reform current agriculture system or even employ new irrigation system in order to increase efficiency and prevent from wasting natural resources, especially water.

\section{References}

[1] Kumar, M. Dinesh, A.K. Malla and S.K. Tripathy, "Economic value off water in agriculture: comparative analysis of a waterscarce and a water-rich region in India.", Water International, 33(2), 214-230. 2008.

[2] Latinopoulos, Dionysis, "Multicriteria decision-making for efficient water and land resources allocation in irrigated agriculture." Environ dev sustain, 11, 329-343, 2007. 
[3] Mansouri, M. and A. Ghiasi, "Estimate the cost of agricultural water of dams with engineering economics approach." Journal of Agricultural Economics and Development, Issue 37, 2002. (In Persian).

[4] Assadi, H., G. R, Soltani and J. Torkamani, "agricultural water pricing in Iran: A Case Study of land under Taleghan dam", Journal of Agricultural Economics and Development, 58, 61-90, 2007. (In Persian).

[5] Tahamipour, M., M. Ataii and S. Abedi, "Calculation of the cost of irrigation water in Fars Province: Application of Engineering Economics." presented at the National Conference on Capabilities Management in the economy of Iran, 2013. (In Persian).

[6] Soleimani, Hossein and Alimorad Hasanli, "Calculation of the water cost, efficiency and added value for major crops in the arid region in Fars, Darab." Iranian Journal of Agricultural Science, 5(1), 2008. (In Persian).

[7] Mortazavi, A., R. Hezare and H. Mousavi, "Calculate the cost of agricultural water in the plain of Qazvin." The first Global Conference on Sustainable Agriculture and Natural Resources, 2013. (In Persian).

[8] Samal, C.K. and Thilotham R Kolanu, "Water pricing and decentralized irrigation management in Andhra Pradesh - Schism between objectives and realities." Paper presented at the 'Deutscher Tropentag', Berlin, 2004.

[9] Renwick M.E., "Valuing water in irrigated agriculture and reservoir fisheries: A multiple-use irrigation system in Sri Lanka." International water management institute, 2001.
[10] Hellegres, Petra and Brian Davidson, "Determining the disaggregated economic value of irrigation water in the Musi sub-basin in India", Agricultural water management, 97(6), 933-938. 2010.

[11] Thabet, Chokri, Ali Chebil and Aymen Frija, "water policy and poverty reduction in rural area: a comparative economy wide analysis for Morocco and Tunisia.” 2014 International congress, Ljubljana, Slovenia, 2014.

[12] Iran Management and Planning Organization, Directive of the basic unit price list of the well field year 2015. (In Persian)

[13] Law of Subsidies Reforming, strategic planning and monitoring of vice president of Iran. (In Persian)

[14] Ministry of Agriculture, Office of Statistics and Information Technology, Agriculture Bank, years 2011-2012. (In Persian)

[15] Ministry of Agriculture, Office of Statistics and Information Technology, Production Cost Bank, years 2011-2012. (In Persian)

[16] Ministry of Energy, Guidance tables for basic information needed to economic studies of supply, transmission and distribution of agricultural water. Management and Planning Organization, Publication No. 174, Technical Affairs Department, 1998. (In Persian)

[17] Ministry of Energy, Basis of determining water cost and subscription rights. Organizations of Water Resources Management, Iran, Water Affairs Department, Ministry of Energy, 2002. (In Persian) 